
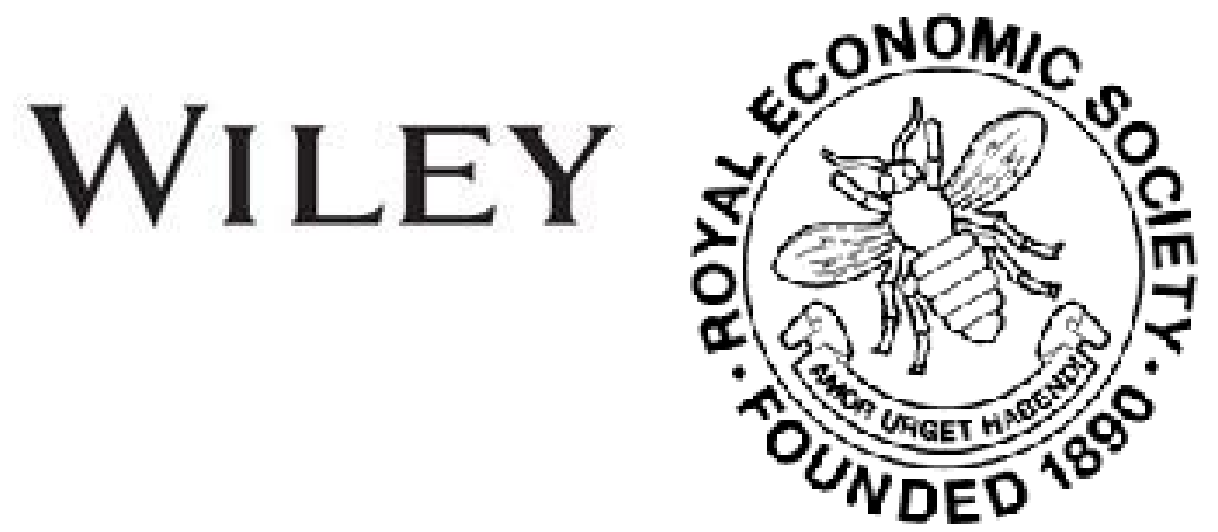

Mr. Pierson on Scarcity of Gold

Author(s): F. Y. Edgeworth

Source: The Economic Journal, Vol. 5, No. 17 (Mar., 1895), pp. 109-112

Published by: Wiley on behalf of the Royal Economic Society

Stable URL: http://www.jstor.org/stable/2956238

Accessed: 27-06-2016 04:22 UTC

Your use of the JSTOR archive indicates your acceptance of the Terms \& Conditions of Use, available at

http://about.jstor.org/terms

JSTOR is a not-for-profit service that helps scholars, researchers, and students discover, use, and build upon a wide range of content in a trusted digital archive. We use information technology and tools to increase productivity and facilitate new forms of scholarship. For more information about JSTOR, please contact support@jstor.org.

Wiley, Royal Economic Society are collaborating with JSTOR to digitize, preserve and extend access to The Economic Journal 
from changes in the inevitable parliamentary treatment of the treaty about the standard For it is, indeed, to every one's interest, that the perplexities of the standard which are involving all nations in common difficulties, should be solved internationally; and even the attempt at an agreement among the Governments would mean such a great success that it would doubtless determine in favour of silver those parliamentary parties which are still wavering.

Julius LANDESBERGER

VIENNA.

\section{Mr. Pierson on Scarcity of Gold.}

THE Bimetallic League ought to translate and circulate an article on Scarcity of Gold which has lately been contributed by the eminent exprofessor, and ex-minister, Mr. N. G. Pierson, to the Dutch periodical De Gids. Lessons of caution and moderation might be accepted from such a teacher. For Mr. Pierson owns to a certain sympathy with the Bimetallist party. Indeed, he has ranged himself on that side unequivocally in his well-reasoned communication to the Gold and Silver Commission (2nd Report), in the course of which he says :

' It is considered a mere truism in this country [Holland] to say that Bimetallism, though highly objectionable if applied in a small country, is the best system imaginable if applied by an international agreement in a large number of civilised States. We thoroughly believe that it would be a great boon to all nations if this system were adopted by the principal countries of Europe and America.'

Mr. Pierson in the article before us proposes two questions: I. Has there been a rise in the purchasing power of gold? II. If so, is the cause connected with gold or goods, or both?

I. The first question involves a consideration of the method of index-numbers. Mr. Pierson prefers the arithmetic to the geometric mean ; not without a certain deference to the 'feeling'-rather than the arguments-of Jevons, in favour of the geometric mean. Distinguishing the simple average of price-variations from that which is weighted according to the importance with respect to some human interest of different commodities, Mr. Pierson very properly ascribes a certain validity to the simpler and more objective mean, for its own sake, and apart from the circumstance that as a matter of fact the two procedures are likely to differ little in result.

As to the period which should be taken as the base of standard, it is a matter of complaint that the advocates of Bimetallism frequently select the 'inflation period' of $1870-75$. If the period $1861-70$ be taken as base, the period 1881-83 compared therewith shows no fall of prices ; according to the index-numbers of Soetbeer and Dr. Kral, based respectively on 114 and 265 commodities. It is true that Mr. Sauerbeck's index-numbers do point to a fall of prices in the interval con- 
sidered. But this discrepancy is due to Mr. Sauerbeck's not having used a sufficient number of data. For observing that thirty-five of Mr. Sauerbeck's articles-or rather forty-one, as six of Mr. Sauerbeck's articles are duplicated-are common to Soetbeer, let us substitute the prices of those articles used by Sauerbeck for the prices used by Soetbeer in his index-number; and that index-number for the period 1881--83 compared with the period $1861-70$ will not be appreciably affected. The discrepancy between the two results is found to be mainly due to the seventy-nine articles which Soetbeer has, and Mr. Sauerbeck has not. Accordingly it would seem that Soetbeer's result is the better founded. Comparing, according to his method, the level of prices in the period 1885--91 with that of $1861-70$, we find a rise in the purchasing power of gold of only some 16 per cent.; whereas it is usual on Bimetallist platforms to speak of a greater rise.

II. Coming to his second question, Mr. Pierson claims against both parties the right to use the term appreciation in the sense of a rise in the purchasing power of gold due to causes affecting gold primarily. He seems to convict a leading monometallist organ of using the term inconsistently. His difference with the Bimetallist leader, Professor Foxwell, is rather about things than words. Mr. Pierson controverts the argument that the depression which has prevailed during recent years must have been due to monetary disturbances: for that there are no other adequate causes for it. There have been many other causes, replies Mr. Pierson, and the cause assigned is not adequate.

To take the latter point first: the Bimetallist in his gloomy picture of the evils of contraction is apt to leave out of account the classes who are benefited by a fall of prices. These are not only creditors not engaged in active industry, but also certain classes of producers. Consider the series of instruments and materials conducive to the production of goods ready for consumption-the goods of the second or higher orders in the phraseology of the Austrian economists. Suppose that a fall of prices occurs first in the goods which are of the highest order, and is propagated downwards. Each class of producers, while his expenses of production are diminished, and until the price of his finished product falls, pending the restoration of economic equilibrium, is benefited. Who shall say that the fall of prices is not as likely to move in the direction which has been described as in the opposite direction? Thus Mr. Pierson is unable to accept Mr. H. H. Gibbs's dictum-that contraction is a greater evil than inflation. In this connexion and with respect to other assertions of unfashionable opinions, Mr. Pierson refers with approbation to Professor Marshall's masterly and impartial evidence before the Royal Commission on the relative values of the precious metals.

The allegation that monetary disturbance is the only adequate cause of the recent depression of trade Mr. Pierson meets by assigning other causes: the very dislocation caused by improvements in production, 
the Protection which became rampant in the seventies, the fall of prices consequent upon recent improvements in transportation and upon the enormous increase of goods which has occurred in so many departments of production-augmentations which Mr. Pierson, following in the steps of Mr. David Wells, exhibits in imposing detail. It is true that some of these causes, especially the last, operated at earlier periods, but not, Mr. Pierson seems to think, in the same degree. Perhaps he has hardly considered the difficulty of proving such a difference in degree.

Mr. Pierson however concludes with confidence that the level of prices did not fall till after 1883, and that the fall is due to canses connected with goods, not gold. But while thus cutting away one of the principal planks of the Bimetallist platform, Mr. Pierson does not attach himself to the opposite party. He makes a distinction between the creed and the propaganda of the Bimetallists. He believes in an international arrangement for steadying the relative value of gold and silver. But this arrangement need not involve the principle of unlimited coinage at a fixed ratio.

One practical difficulty in the application of that principle may be stated in the form of a dilemma as follows. If the ratio adopted is considerably different from $15 \frac{1}{2}$ (silver): 1 (gold), say 25 to 1 , then the expense of introducing the change would be enormous in view of the depreciation of the existing stocks of silver current at the rate of $15 \frac{1}{2}: 1$. 'If I reckon rightly,' says Mr. Pierson, ' it would cost Holland, exclusive of her colonies, about 52 million florins; France about 950 million francs.' But if the $15 \frac{1}{2}$ is to be adopted, then there is likely to be caused an immense appreciation of money throughout the East - the last result that a consistent Bimetallist can approve.

Mr. Pierson's own plan for keeping the relative value of gold and silver constant is a modification of the general idea that the central banks in Europe-in the United States the Treasury-should be required to purchase the metals at a fixed price. But perhaps it is unnecessary to go into ${ }_{i}^{5}$ particulars, as Mr. Pierson admits that there are three fatal objections to the practical adoption of his plan.

While pointing out the difficulties of remedial action, Mr. Pierson does not, like the monometallists, deny the existence of monetary disease. It is a sad conclusion that things are in a bad way. It is a poor consolation that they might have been worse. For instance, the success of the monetary experiment in the Dutch colonies is much more perfect than could with reason have been expected.

I'hese conclusions are corroborated by a communication which Mr. Pierson has made to the January number of the Dutch monthly De Economist. In this number (p. 64) Mr. Pierson discusses the statistics of prices which $\mathrm{Mr}$. Heinz, the chief of the Hamburg Statistical Bureau, has prepared in continuation of the work of Soetbeer [compare the statistics referred to in the Ecovourc 
JournaL, vol. IV., p. 201]. Soetbeer's series of index-numbers was interrupted by tariff-regulations which disturbed the prices of several commodities in such wise as to render them after 1891 no longer commensurate with the prices of the same articles for earlier years. Accordingly Mr. Heinz has to confine himself to articles which have been imported by sea into Hamburg. Operating with 137 articles of this class, Mr. Pierson constructs a series of index-numbers which is continuous from the year 1850 to the date of the most recent returns. Unfortunately for the comparison with Soetbeer's figures, Mr. Pierson has been compelled, by the imperfection of his materials, to take as the base of the new index-numbers the year 1850, instead of the period 1847-50 which Soetbeer had taken. But in spite of this discrepancy, and the more serious difference in the mode of construction, the parallelism between the two sets of index-numbers is wonderfully close, as the annexed figures show :

\begin{tabular}{|c|c|c|c|c|}
\hline \multicolumn{2}{|l|}{1850 or $1847-50^{1}$} & $\begin{array}{l}\text { Heinz. } \\
100\end{array}$ & & $\begin{array}{l}\text { Soetbeer } \\
100\end{array}$ \\
\hline $1851-55$ & $\ldots$ & & & \\
\hline $1856-60$ & ............ & $119 \cdot 88$ & $\ldots$ & $120 \cdot 91$ \\
\hline $1861-65$ & & $120 \cdot 23$ & ...... & $123 \cdot 59$ \\
\hline $1866-70$ & $\cdots$ & $118 \cdot 44$ & $\ldots$. & $123 \cdot 57$ \\
\hline-75 & $\ldots$ & 131.57 & & $133 \cdot 29$ \\
\hline $1876-80$ & .................. & $120 \cdot 88$ & $\ldots$ & 12 \\
\hline & ......... & $114 \cdot 73$ & $\ldots .$. & $117 \cdot 68$ \\
\hline $1886-90$ & & $105 \cdot 5$ & & $104 \cdot 40$ \\
\hline 1891 & & $111 \cdot 55$ & …................ & $109 \cdot 19$ \\
\hline
\end{tabular}

It will be observed that the new series like the old one, when the ' inflation period' of 1871-75 is left out of account, shows no signs of appreciation due to monetary disturbances of that period: thus confirming Mr. Pierson's view that the appreciation which we now experience is due to causes connected with goods rather than gold.

The congruity between the two Hamburg index-numbers is such that they mutually support each other. On the one hand additional strength is imparted to the conclusion which Mr. Pierson had obtained on independent grounds (above p. 111), that Soetbeer's indexnumbers are more trustworthy than Mr. Sauerbeck's. On the other hand the index-numbers constructed by Messrs. Heinz and Pierson, having agreed closely with Soetbeer's for forty years from 1850 to 1891, may be presumed to be almost as trustworthy as Soetbeer's indexnumbers would have been for the years after 1891 .

If we compare the period 1886-93 with the period 1861-70 taken for base-as recommended by Mr. Pierson in his study on the scarcity of gold (above p. 109)-we shall find from Mr. Heinz's materials, the index-number 88.8; from Mr. Sauerbeck's, 69.5. According to Mr. Pierson the former measure of appreciation is the more trustworthy; but the latter is more convenient for the advocates of Bimetallism.

F. Y. EDgeworth

11850 for Heinz's, 1847-50 for Soetbeer's index number. 